IZA DP No. 5315

Determinants of Further Training:

Evidence for Germany

Christian Grund

Johannes Martin

November 2010 


\title{
Determinants of Further Training: Evidence for Germany
}

\author{
Christian Grund \\ University of Würzburg \\ and IZA
}

Johannes Martin

University of Würzburg

\section{Discussion Paper No. 5315 \\ November 2010}

\author{
IZA \\ P.O. Box 7240 \\ 53072 Bonn \\ Germany \\ Phone: +49-228-3894-0 \\ Fax: +49-228-3894-180 \\ E-mail: iza@iza.org
}

\begin{abstract}
Any opinions expressed here are those of the author(s) and not those of IZA. Research published in this series may include views on policy, but the institute itself takes no institutional policy positions.

The Institute for the Study of Labor (IZA) in Bonn is a local and virtual international research center and a place of communication between science, politics and business. IZA is an independent nonprofit organization supported by Deutsche Post Foundation. The center is associated with the University of Bonn and offers a stimulating research environment through its international network, workshops and conferences, data service, project support, research visits and doctoral program. IZA engages in (i) original and internationally competitive research in all fields of labor economics, (ii) development of policy concepts, and (iii) dissemination of research results and concepts to the interested public.
\end{abstract}

IZA Discussion Papers often represent preliminary work and are circulated to encourage discussion. Citation of such a paper should account for its provisional character. A revised version may be available directly from the author. 
IZA Discussion Paper No. 5315

November 2010

\section{ABSTRACT}

\section{Determinants of Further Training: Evidence for Germany}

Based on a German representative sample of employees we explore the relevance and development of further training in private sector firms. We focus on formal training and explore possible individual and job-based determinants of its incidence. We also show changes over time during a 20 year observation period from 1989 to 2008 . Most hypotheses are supported by the empirical evidence. Job status and firm size are the most relevant characteristics for training participation. Furthermore, our analyses reveal a general trend of rising training rates from 1989 to 2008 indicating an increased importance in the German labor market.

JEL Classification: M53

Keywords: further training, GSOEP, human capital, panel data

Corresponding author:

Christian Grund

Department of Business and Economics

University of Würzburg

Sanderring 2

97070 Würzburg

Germany

E-mail: ch.grund@uni-wuerzburg.de 


\section{Introduction}

Due to the increasing worldwide competition among firms it is necessary especially for firms in economically developed countries to have productive employees. In addition, occupational relevant knowledge (human capital) is important from an individual perspective in order to enhance present and future employability. General knowledge acquired in school or university may not be sufficient for most employment relationships, but has to be complemented by additional knowledge and abilities for the specific job. Besides, knowledge previously learnt may obsolesce especially in dynamic markets with a lot of product and procedural innovations so that the use of further (or continuous) training ${ }^{1}$ in firms may be reasonable in order to refresh and adjust employees' human capital. Combined with the problem of aging workforces, further training seems to be a necessity for both employees and firms to survive in the market. Therefore, many firms actually offer some kind of informal or formal further training to their employees.

As competition has increased during ongoing globalization, we may expect to observe growing participation in training over the last decades. In this contribution, we focus on the German case. Here, the employer association and trade unions agree that further training is a key to competitiveness and employability (Confederation of German Employers 2007, Confederation of German Trade Unions 2009). This is in line with the European Commission stating that "skills matter. (...) They are the best insurance against unemployment (...) [and] are a major component of the [European] Union's productivity, competitiveness and innovation” (European Communities 2009, p. 2).

\footnotetext{
${ }^{1}$ In this paper, we use the terms "further training”, “continuous training”, "vocational training”, "occupational training” and simply "training” in a widely synonymous way.
} 
However, further training is most probably not equally reasonable for all groups of employees and firms. One can interpret further training as a form of investment, because there are also costs that emerge in terms of direct costs for the training course or opportunity costs of time when visiting this course. These costs have to be amortized by possible benefits afterwards. We expect that there are significant differences about the amount of these benefits between different groups of employees. This should result in different rates of training participation for different groups. Hence, the aim of this study is to empirically analyze possible individual and job-based determinants that affect the decision if a worker receives further training. We do not address consequences of further training, see instead Pannenberg (2001), Büchel and Pannenberg (2004) or Wolter and Schiener (2009) for the impact on wages, Georgellis and Lange (2007) for the impact on job satisfaction or Zwick (2005) for the impact on establishment productivity in Germany.

This is not the first paper on this issue. Previous contributions for the German case include some cross-section studies for single years of the German Mikrozensus, which is part of the Labour Force Survey of the European Union. ${ }^{2}$ Hubert and Wolf (2007) and Leber and Möller (2008) calculated yearly training rates of employees of 0.15 in 2003 respectively 2004 and show that training rates are higher for better educated an in large firms, for instance. Some other previous studies use data of the German SocioEconomic Panel (GSOEP). Most of these studies are also restricted to a cross-section analysis (Behringer 1999, Pischke 2001, Büchel and Pannenberg 2004). To the best of our knowledge, there are only two papers that use data of more than one year. However, none of these makes use of panel estimations. Pannenberg (1998) analyzes the relevance of training for West Germans during the time span 1986 to 1993 based on the GSOEP 
waves of 1989 and 1993 and finds that 0.38 of employees participated in formal training at least once in this time span. Participation rates were higher for male, better educated and in large firms. The paper probably closest to our contribution is a study by Georgellis and Lange (2007), although they rather focus on effects of further training with respect to job satisfaction. They extend the analysis the GSOEP wave of the year 2000 and observe training participation rates of 0.28 in three year periods for West Germans.

In this contribution we extend the analysis to the year 2008 so that for the first time developments over two whole decades can be observed. In contrast to prior studies we apply panel estimations. We also include East Germans after re-unification so that we can explore the transformation process with respect to formal training. In addition, we exclude employees from the public sector. We think that participation rates are more intuitive on a yearly base, while previous studies use rates in a three year period by the majority. We derive hypotheses for several individual and job-based characteristics of participation in formal training.

We will go on by deriving our hypotheses for individual and job based characteristics of further training (section 2). We mainly focus on human capital theory. The data and variables are presented in section 3 followed by the outline of our results in section 4 . Section 5 concludes.

\section{Theoretical considerations and hypotheses}

Since further training is usually not for free - as mentioned above -, it can be characterized as an investment. These investments in human capital have to be paid by the employees and/or firms. Trainings can be distinguished with respect to several 
attributes: The outcome of training may rather have the character of general or firmspecific human capital. The initiative and the funding of the training may be assigned either to the firm or to the employee. The training may either be given in a formal program or informal (on-the-job) training. And one can also distinguish between internal and external programs.

We focus on formal training programs for employees in our empirical investigation so that we have this kind of further training in mind, when deriving hypotheses of possible determinants. In the following two sub-sections we will argue that the provision of further training may differ across subgroups of employees and jobs.

\subsection{Individual characteristics}

We first consider possible individual characteristics of participation in further training. Employees' age may be relevant due to several reasons. A main result of human capital theory is that investments are sensible rather for young employees because of a larger scope for amortization (Becker 1962). Therefore, we usually should not observe further training for the elderly. On the other hand, there may no need for formal trainings for young employees who just completed their apprenticeship or graduated from university, when age acts as a proxy for labor market experience. Therefore, medium aged employees may have higher training probabilities than younger ones, because they have to update occupational knowledge and skills. We conclude:

Hypothesis 1 (Age):

Participation in further training is inversely u-shaped in age. 
Direct discrimination is forbidden in European labor markets. However, Erlinghagen (2005) states that women have shorter periods of realized tenure in Germany. Hence, some kind of statistical discrimination may still be relevant if firms anticipate shorter expected tenure periods of female employees. If this is true, we can argue that employers are less willing to provide formal training programs for women, because of a lower probability that investments amortize. If employees have to bear the training costs, the same argument holds. Women rather will forbear from investments in further training. This leads to

Hypothesis 2 (Sex):

Women have lower probabilities of training participation than men.

The case of foreign employees is supposed to be similar to that of women. Differences for foreigners compared to natives with respect to wages and promotions are widely discussed in the literature (see e. g. Constant and Massey (2005)). Therefore, there should also be evidence for an unequal treatment by the employers with respect to decisions on training participation. Second, employers may expect that average tenure is shorter for foreign employees because they do not have social and/or cultural roots in Germany and that they return to their home country after some years. Then, the training rate should be lower for foreign people. Finally, participation in courses taught in German may sometimes be hindered by language problems of foreigners. We therefore state:

Hypothesis 3 (Foreigners):

Foreigners are less involved in further training. 
The relation between employees' schooling and participation in further training is less straightforward. On the one hand it can be easier for more capable persons to benefit from both general education and further training. In this context, further training may be a complement to previous human capital investments such as schooling. Better educated employees are more efficient in learning so that further training is rather beneficial for them (Mincer 1992, p. 18). The latter argument is enhanced, if certain schooling degrees act as trustworthy signals for motivation in the sense of Spence (1973) with respect to educational investments.

On the other hand further training may also act as a substitute to schooling. Employees without certain knowledge from school such as foreign languages may catch up things in formal training programs. Decreasing marginal benefits may be another argument for firms rather to provide further training for less educated employees. We therefore formulate two opposing hypotheses. It is an empirical issue, which argument dominates in practice. ${ }^{3}$

Hypothesis 4 (Schooling):

a) Better educated employees get more further training.

b) Better educated employees get less further training.

\subsection{Job- and firm-based characteristics}

First, tenure is supposed to be a relevant characteristic. Employees may face formal internal trainings directly after recruitment in order to learn firm-specific tools and processes or to get involved into the specific corporate culture. After these initial courses the probability of training should then diminish. Further training can become

3 We cannot test these two each other empirically due to lack of appropriate data. 
relevant again for those employees with higher tenure to be updated on procedural or product innovations in the firm. This leads to our

\section{Hypothesis 5 (Tenure):}

Participation in further training is u-shaped in tenure.

This argument is quite different compared to what we argued above with respect to age: Here, we focus on new intra-firm tools and processes that require further training and not on innovations in the occupational environment concentrating on the individual age (as a proxy for labor market experience). For example, an accountant has to learn new legal rules (occupational environment) and also has to familiarize himself with the new company IT system (intra-firm environment).

The contracts for some employees are limited to a certain period of time. Limited work contracts can have several functions: For example, they can be used to enhance workforce flexibility since firms do not face any direct separation costs like severance payments when terminating limited contracts. Furthermore, they may act as a solution for the adverse-selection problem resulting from asymmetric information in the labor market (Akerlof 1970), as they are similar to a probation time whilst the employer can observe the abilities of the employee. Even if there is the possibility that the contract becomes renewed, the expected duration of the employment relationship is shorter in a situation with a limited contract, compared to one with an unlimited contract. In consequence, an amortization is less likely. This leads to

Hypothesis 6 (Limited work contract):

The probability of being trained is lower for people with a limited work contract. 
Additionally, further training shall be more relevant for certain jobs. Employees with responsible jobs and comprehensive tasks face a variety of necessary skills. The larger the complexity of necessary skills is, the higher is the probability that some skills or knowledge has to be accumulated by formal trainings. For instance, a simple member of a work team, who becomes promoted to the position of team leader, has to acquire certain skills of managing a team. These skills may include handling intra-team conflicts in an effective way or setting the right incentives to work, for instance. It is likely that these competences are taught in formal courses. Another possible explanation is the following: Ceteris paribus firms promote employees which are more productive than others. Hence, a higher hierarchical level could stand for a higher individual productivity of the employee. This productivity could depend on individual characteristics like schooling or age, but also on the individual motivation of the employee (that cannot be directly observed in our data). If this is true, we can assume that employees on higher levels are on average higher motivated and more productive. From the firm perspective it is better to provide training courses to relatively motivated employees because of the expected better amortization of investments. We therefore state:

Hypothesis 7 (Job status):

Participation in further training increases in the level of job responsibility.

Formal training is supposed to be more relevant in large firms due to several reasons. First, the fix costs of training arrangements can be distributed on more employees, which lead to economies of scale (Haber 1991). Second, it is likely that larger firms have better opportunities to re-allocate tasks, if certain employees are absent due to 
training participation (Pannenberg 1995, p. 54). Third, larger firms are more likely to implement internal labor markets (Doeringer and Piore 1971), which lead to longer expected tenure periods and less risky training investments (Holtmann and Idson 1991).

Hypothesis 8 (Firm size):

Employees of large firms get more further training than those of small firms.

The expected benefit of formal training arrangements may also increase in the weekly working time of the employee. The firm benefits especially from the increased individual productivity, if the trained employee works many hours (Behringer 1999, p. 39). This leads to:

Hypothesis 9 (Working time):

Participation in further training increases with actual working hours.

\subsection{Historical and contemporary background}

Competition among firms increased over the last decades due to ongoing globalization. If (minimum) wages are fixed by collective agreements or guaranteed benefits of the welfare state in case of unemployment like in Germany and worldwide competition becomes harder, firms are forced to maintain or increase employees' productivity. Further training might be an appropriate opportunity. This leads to

Hypothesis 10 (Time):

Participation in further training increased over time. 
The German case is most likely be influenced by re-unification in 1990. The transformation process in East Germany at the beginning of the 1990s led to a necessary adaption to the market economy. Therefore, employees had to learn corresponding knowledge and skills on short notice so that our last conjecture is

\section{Hypothesis 11 (Region):}

East German employees face extraordinary high rates of further training directly after re-unification.

Table 1 shows a short summary of our hypotheses. We now go on by describing our data set and the methodology for analyzing the participation in further training in Germany.

\section{Table 1: Summary of hypotheses}

\section{Individual characteristics:}

Age inversely u-shaped

Female $(-)$

Foreigner

Years of schooling

$(+)$ vs. $(-)$

Job- and firm-based characteristics:

Tenure u-shaped

Limited work contract

Job status (Level of job responsibility)

Firm size

Working time

$(+)$

\section{Historical and contemporary background}

Year of observation

East Germany

$(+)$ (especially in 1993) 


\section{Data, Variables and Methodology}

We make use of the German Socio-Economic Panel (GSOEP), which is a representative data set of people living in Germany. Individuals are asked on a yearly base about several areas of life including general attitudes and their employment relationship next to usual demographics. Detailed questions on further training are asked in the years 1989, 1993, 2000, 2004 and 2008. We restrict our sample to full- and part-time employees with a minimum and maximum age of 20 and 65 (the regular retirement age) respectively. We also exclude civil servants and employees from the public sector from our analysis as we want to explore further training in the private sector. The data set consists of 18,375 observations from 10,363 different persons. We, therefore, have an unbalanced panel (1989: $n=2,502 ; 1993$ : $n=3,693 ; 2000: n=3,332 ; 2004: n=4,492,2008$ : $\mathrm{n}=4,356$ ). Differences in sample sizes across years can be explained by the integration of East Germans from the year 1991 onwards, some panel refreshments and general panel mortality.

In Table 2 we provide descriptive statistics about our data set. We distinguish between years in order to show some developments over time. Foreign people are somewhat over-represented in the first years of our sample (in 1989 (2008): 0.324 (0.063) compared to 0.077 (0.069) of the whole workforce in Germany, see German Federal Ministry of Labour and Social Affairs 2009, table 2.7). Therefore, we make use of the GSOEP weighting variables as suggested by Frick, Haisken-DeNew, Spiess, and Wagner (2005) so that our data set is continuously representative for the German workforce. 
Table 2: Descriptive statistics

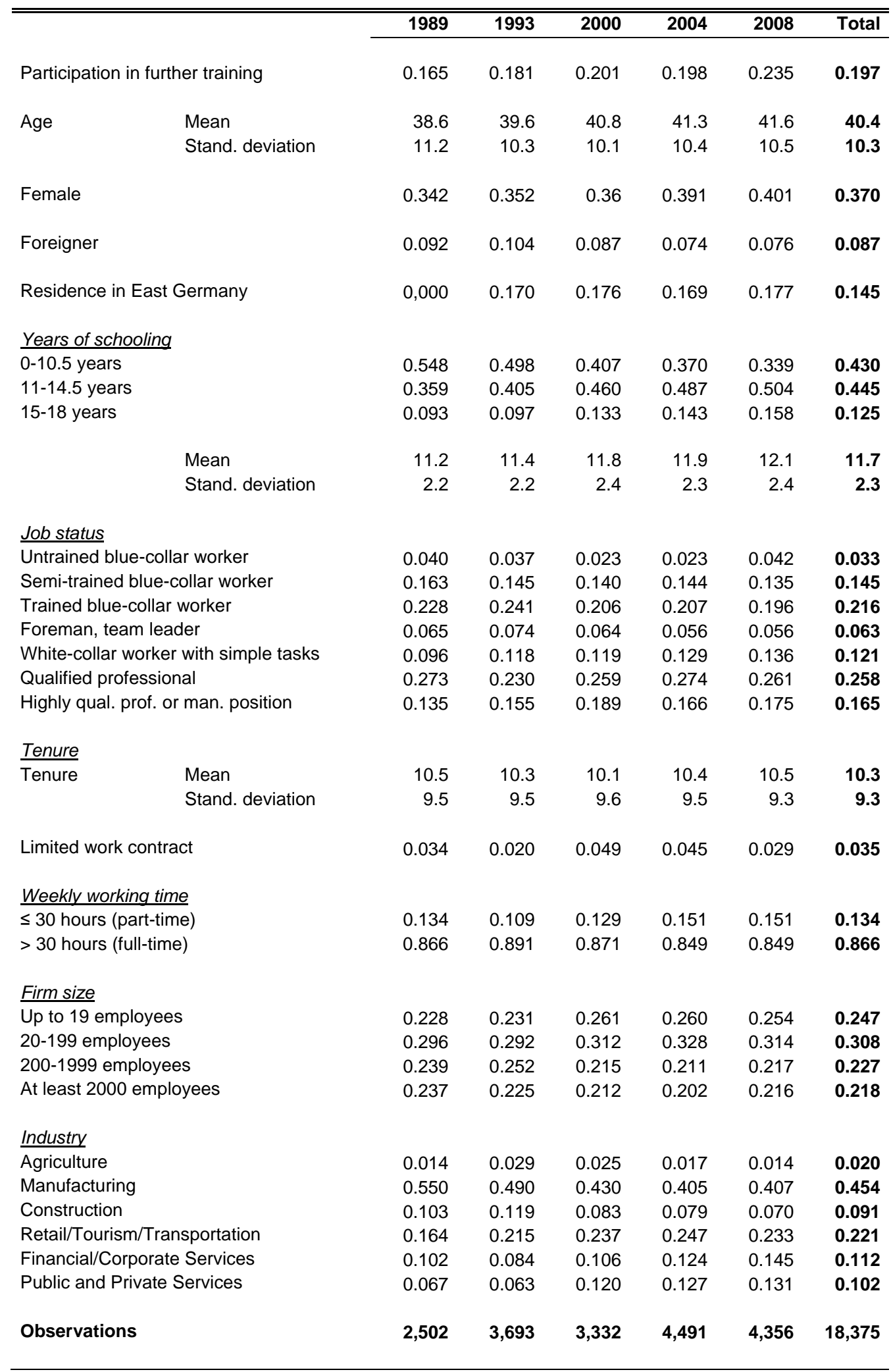

Note: The results are calculated with cross-sectional weights. 
Apparently, employees become older over the observed period. Besides, the fraction of women and the average amount of years of schooling increase. The structural change from the secondary to the tertiary sector is captured by the decreasing fraction of bluecollar workers in the sample. The average tenure decreases from 10.5 years in 1989 down to 10.1 years in 2000, but increases again up to 10.5 years in 2008 . Correspondingly, the fraction of employees with a temporally limited work contract rises from 0.034 in 1989 up to 0.049 in 2000 and falls again to 0.029 in 2008. The distribution with respect to firm size shows off a smooth shift to smaller firms.

Individuals are asked in the GSOEP to give some detailed information about participation in formal training, for example about the date and duration of the course. Combined with the information about the date of the interview, we are able to compute a binary variable "participated in further training" with " $1=y e s$ " if the employee has attended at least one course in the 12 month prior to the interview and " $0=$ no" if not. This variable acts as the dependent variable of our multivariate analysis. This approach allows us to directly speak of "yearly further training rates” of subgroups.

Some previous studies (Pannenberg 1995, Behringer 1999, Pischke 2001, Büchel and Pannenberg 2004, Georgellis and Lange 2007) have used an alternative approach. In GSOEP, respondents are also asked: "How many courses for further professional education have you attended in the last three years?” In these studies, employees denote a training participation if they state a number higher than zero with respect to this question. In our opinion, employees should be better able to review the one year period and we hope to get more valid results. Another advantage of this approach is that we can compute yearly training rates for different subgroups and compare them over time. 
To test our hypotheses we make use of several variables of the GSOEP. Since we want to find out the characteristics that account for participating in training in year $t$, we use the information of the individual and job-based characteristics of year t-1 (which is possible due to the panel structure of the GSOEP). Thus, we make sure to use the information from before the training measurement, since we observe only courses in the one year period.

We have information for individuals' age, sex, schooling and the observation year. We also distinguish between German and foreign employees. With respect to our considerations on job- and firm-based characteristics, we are aware of the individual tenure (in years), job status (seven categories of blue-collar and white-collar jobs differing in the responsibility of tasks), actual working time (hours per week) and the temporally limitation of the work contract (dummy). Firm size is measured with the number of employees of the firm in which the respondent works (four categories). We also control for industries (six categories). Analyzing the historical and contemporary background, we take year dummies into consideration and have also information on the region people live in (East Germany vs. West Germany).

We will start with some descriptive statistics by comparing further training rates between different subgroups and between the observed years. Furthermore, we also apply a binary probit approach with the dummy "Further training" as the dependent variable (1=”yes”, $0=$ ="no”). The arguments in section 2 suggest that several individual $(x)$ and job-based $(y)$ characteristics and the contemporary background (z) may affect the participation in further training so that

$$
\text { Further Training }=\alpha+x^{\prime} \beta+y^{\prime} \delta+z^{\prime} \chi+\varepsilon
$$


describes our empirical model. The effect of the independent variables on the probability of participation in further training is indicated by the corresponding regression coefficients $\beta$, $\delta$, and $\chi$, whereas $\alpha$ represents the intercept.

We start by analyzing the pooled data set including all observations from 1989 until 2008. Therefore, we make use of a random effects binary probit model for several reasons. First, we want to analyze the impact of time-invariant determinants like sex or nationality. This would not be possible by using a fixed effects model. Second, our data set has an unbalanced structure with many employees with observations in only one year. These observations would not be taken into account in a fixed effects model (Wooldrige 2002, p. 580). Finally, for those persons with information in multiple years and variation in the dependent variable (about 2,500 persons), the result of the Hausman test is not significant, which indicates that a random effects model is more efficient compared to a fixed effects model. Subsequently, we investigate the single years' data by applying cross section binary probit models.

\section{Results}

\subsection{Descriptive Statistics}

Figures 1 and 2 indicate a first impression of yearly training rates of employees. There is an upward trend in the incidence of formal training (Figure 1a). Whereas 0.165 of employees have been trained in 1989, the fraction has increased to 0.235 in 2008. As one can see from Figure 1b, foreigners have considerable lower rates of training than German employees in all five years. Training rates directly after the German reunification in 1990 are somewhat higher in East Germany, which is in line with our prediction. In the subsequent years, East and West German employees have a nearly identical probability of being trained (Figure 1c). 
Figure 1: Participation rates in further training over time (individual characteristics and historical background)

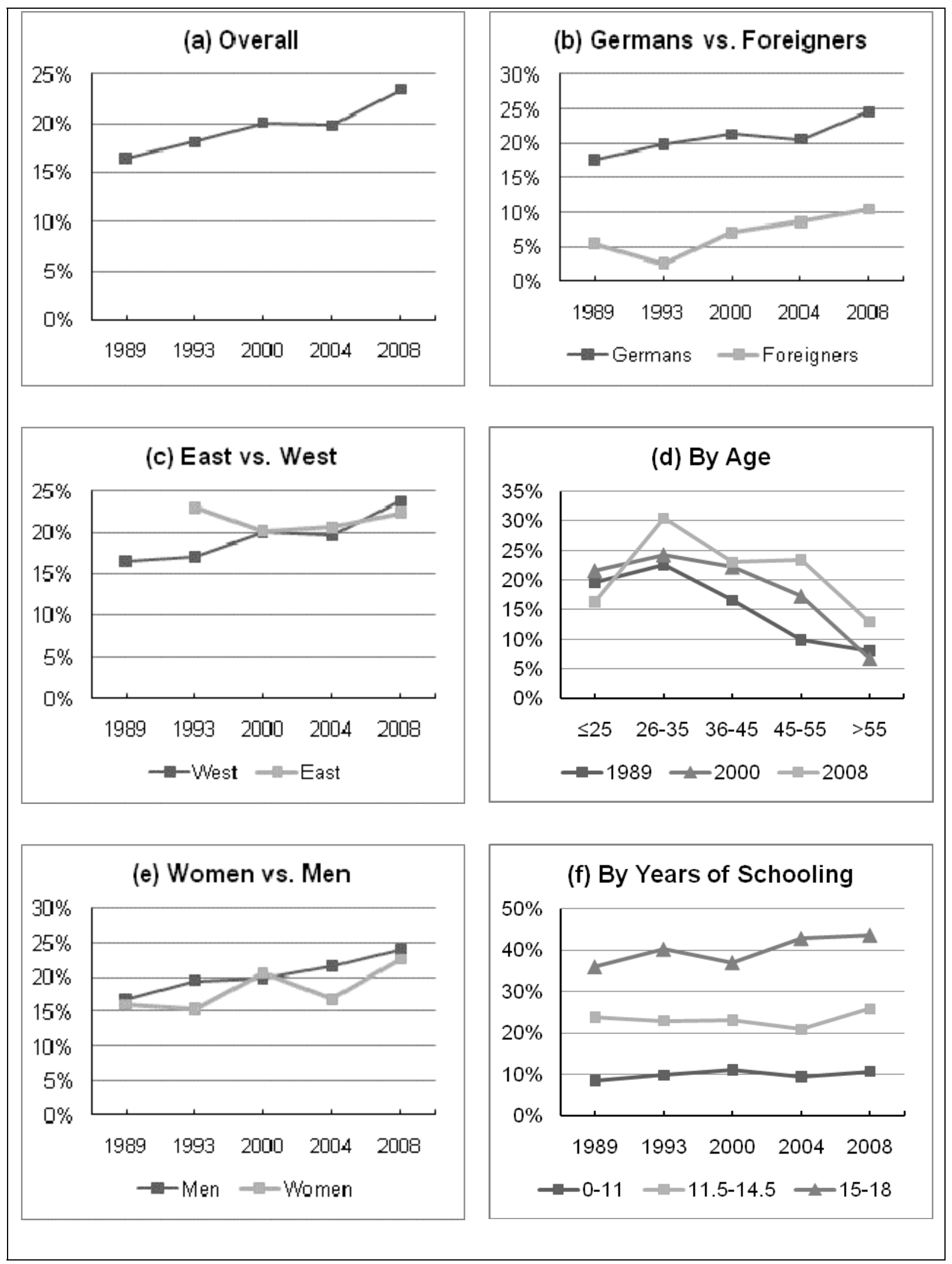

Note: The results are calculated with cross-sectional weights. 
Figure 1d illustrates the predicted inversely u-shaped relation between age and training participation for certain years, which is in accordance with our conjecture. Training rates do not differ considerably between male and female employees. In contrast, employees face different training rates with respect to education. Rates for individuals with at least 15 years of schooling (university graduates) are about 16 percentage points higher as for employees with 11.5 up to 14.5 years and even on average 30 percentage points higher as for individuals with at most 11 years of schooling.

Participation rates in further training with respect to different job- and firm-based characteristics are presented in Figure 2. First there is a slight inversely u-shaped curve for tenure in 1989. In later years, this picture disappears and the training rates are nearly stable over all tenure groups (Figure 2a). A limited work contract seems to have no clear link with participation in further training. At most, lower training rates for individuals with a limited work contract can be observed in the year 2008 (Figure 2b). Figures 2c and $2 \mathrm{~d}$ show training rates for different groups of blue-collar and white-collar workers. Training rates increase in the job responsibility. It is also evident that white-collar worker have on average higher training rates than blue-collar workers. When looking at different firm size categories (Figure 2e), no considerable differences in training rates between the smallest size ( $<20$ employees) and the second smallest group (20-199 employees) can be shown. However, people in bigger firms have higher rates. Another interesting point is that the development over time suggests a convergence of training rates across firm size categories. Last, full-time employees report considerably more often participation in training than individuals in part-time employment relationships (see Figure 2f). 
Figure 2: Participation rates in further training over time (job- and firm-based characteristics)

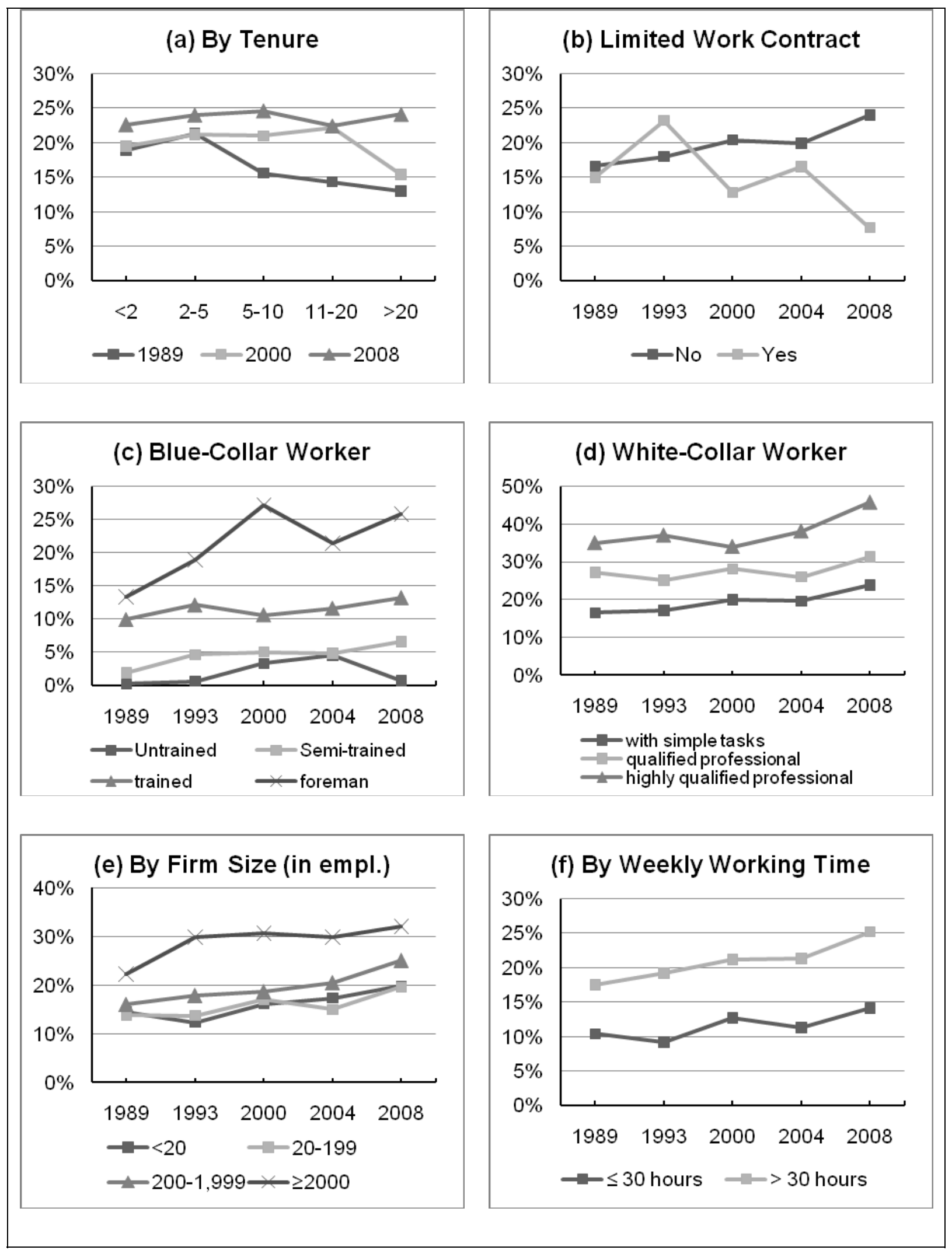

Note: The results are calculated with cross-sectional weights. 
To sum up, most of these illustrations are in line with the hypotheses derived above in section 2. However, the results of these bivariate illustrations cannot be interpreted as effects. We therefore proceed with a multivariate analysis to test our hypotheses.

\subsection{Multivariate Analysis}

Our dependent variable is the dummy variable "Further Training" (as explained in chapter 3). We start with presenting our results gained from the random effects probit model.

Most of our hypotheses are supported by the results of the binary probit estimate (see Table 3): Participation in further training is significantly lower for females, foreigners and West Germans over the whole observation period on average. We also find an inversely u-shaped effect for age with a maximum at 27 years. As predicted, the probability of being trained increases in the level of the job responsibility. White-collar workers denote on average more training than blue-collar workers. Schooling is positively associated with the probability of training. As expected, there is a u-shaped effect of tenure on further training (minimum at 15 years). ${ }^{4}$ Furthermore, we find a positive effect for the actual working hours per week and a negative effect for a limited work contract. Employees in bigger firms face a higher training probability. There is no significant difference between the lowest and the second-lowest firm size category, though. Our hypothesis with respect to the general trend over time is mainly supported. Training probability has increased significantly from 1989 to 2000 and from 2000 to 2008. However, there is no significant increase from 1993 to 2000 and again from 2000 to 2004. A joint test for the set of year dummies reveals a high significance, though.

\footnotetext{
4 However, this effect is not very big and not independent from the effect of age since increasing tenure of an individual goes automatically along with an increasing age. A joint consideration of both tenure and age reveals a constantly negative influence on training participation, which means that the age effect overcompensate the effect of tenure in higher years.
} 
Table 3: Determinants of further training (random effects binary probit estimate, pooled)

\begin{tabular}{|c|c|c|}
\hline & $\begin{array}{c}\text { Random effects binary probit } \\
\text { Participation in training (1=yes) }\end{array}$ & Marginal effects \\
\hline Age & $0.038^{\star \star \star}(0.012)$ & 0.007 \\
\hline $\mathrm{Age}^{2} \times 100$ & $-0.070^{\star \star \star}(0.014)$ & -0.012 \\
\hline Female & $-0.151^{\star \star \star}(0.040)$ & -0.026 \\
\hline Foreigner & $-0.487^{\star \star \star}(0.064)$ & -0.069 \\
\hline Residence in East Germany & $0.127^{\star \star \star}(0.039)$ & 0.023 \\
\hline \multicolumn{3}{|l|}{$\underline{\text { Job status }}$} \\
\hline Untrained blue-collar worker & $-1.325^{\star \star \star}(0.163)$ & -0.105 \\
\hline Semi-trained blue-collar worker & $-0.948^{\star \star \star}(0.082)$ & -0.111 \\
\hline Trained blue-collar worker & $-0.462^{\star \star \star}(0.067)$ & -0.069 \\
\hline Foreman, team leader & --- & --- \\
\hline White-collar worker with simple tasks & $-0.202^{\star \star \star}(0.078)$ & -0.032 \\
\hline Qualified professional & $0.167^{\star \star}(0.068)$ & 0.031 \\
\hline Highly qualified professional or managerial position & $0.338^{\star \star \star}(0.072)$ & 0.068 \\
\hline Years of schooling & $0.043^{\star \star \star}(0.008)$ & 0.008 \\
\hline Tenure (in years) & $-0.014^{\star \star \star}(0.005)$ & -0.003 \\
\hline Tenure $^{2}$ x 100 & $0.046^{* * *}(0.015)$ & 0.008 \\
\hline Actual work time per week & $0.007^{\star \star \star}(0.002)$ & 0.001 \\
\hline limited work contract & $-0.169^{\star \star}(0.081)$ & -0.027 \\
\hline \multicolumn{3}{|l|}{ Firm size } \\
\hline Up to 19 employees & $-0.024(0.042)$ & -0.004 \\
\hline 20-199 employees & --- & --- \\
\hline 200-1999 employees & $0.217^{\star \star \star}(0.042)$ & 0.041 \\
\hline At least 2000 employees & $0.404^{\star \star \star}(0.042)$ & 0.082 \\
\hline \multicolumn{3}{|l|}{ Industry } \\
\hline Agriculture & $-0.019(0.104)$ & -0.003 \\
\hline Manufacturing & --- & --- \\
\hline Construction & $-0.201^{\star \star \star}(0.062)$ & -0.032 \\
\hline Retail/Tourism/Transportation & $-0.069(0.043)$ & -0.012 \\
\hline Financial/Corporate Services & $0.150^{\star * \star}(0.050)$ & 0.028 \\
\hline Public and Private Services & $0.370^{\star \star \star}(0.052)$ & 0.078 \\
\hline \multicolumn{3}{|l|}{ Year } \\
\hline 1989 & $-0.121^{\star \star}(0.054)$ & -0.020 \\
\hline 1993 & $0.024(0.045)$ & 0.004 \\
\hline 2000 & --- & --- \\
\hline 2004 & $0.001(0.041)$ & 0.000 \\
\hline 2008 & $0.146^{\star \star \star}(0.042)$ & 0.027 \\
\hline Intercept & $-2.153^{\star \star \star}(0.267)$ & \\
\hline Observations (persons) & $18,375(10,363)$ & \\
\hline McFadden Pseudo-R² & 0.12 & \\
\hline
\end{tabular}

Notes: Robust standard errors in parentheses. Marginal effects are calculated at the means of other independent variables. 
Looking at marginal effects, we find the most pronounced relations to training participation for being a foreigner, job status and firm size. Training participation rates are seven percentage points lower for foreigners than for Germans, 17 points larger for highly qualified white-collars than for unskilled blue-collar workers and nine points higher in large firms with at least 2,000 employees than in small firms with less than 20 employees.

Our descriptive illustrations give some indications that there are differences with respect to training rates for different subgroups between the single years. Therefore, we also present the results of binary probit regressions on the base of single years' data sets (see Table 4). A significant inversely u-shaped correlation between age and training is only observable in 2004 (maximum at 33 years). Women denote significant lower training rates than men only in 2004. There is a significant lower probability of being trained for foreigners in 1993, 2000 and 2004. However, the coefficients become smaller over time, which indicates a decreasing importance of being a foreigner for training participation. As predicted, East Germans have a significant higher training rate directly after the German re-unification.

There is a clear link between the level of job responsibility and training probability in all five years. Furthermore, white-collar workers denote continuously higher rates than blue-collar workers. Years of schooling are positively correlated with training from 1993 on. We get the predicted u-shaped relation between tenure and training probability only in 2004 (with a minimum of 17 years). Working time and training show a significant link in 1989, 2004 and 2008. Only in the year 2008, employees with a limited work contract denote a lower training probability. The evidence for firm size is not as clear as in our random effects estimation, as we get continuously significant 
coefficients only for the biggest firm size. However, when looking on the sign of the other coefficients, we can see the predicted positive link between firm size and training. The goodness of fit, measured by the Pseudo- $\mathrm{R}^{2}$, decreases over time. Therefore, other (unobserved) determinants become more important.

Table 4: Determinants of further training (binary probit estimates; single years)

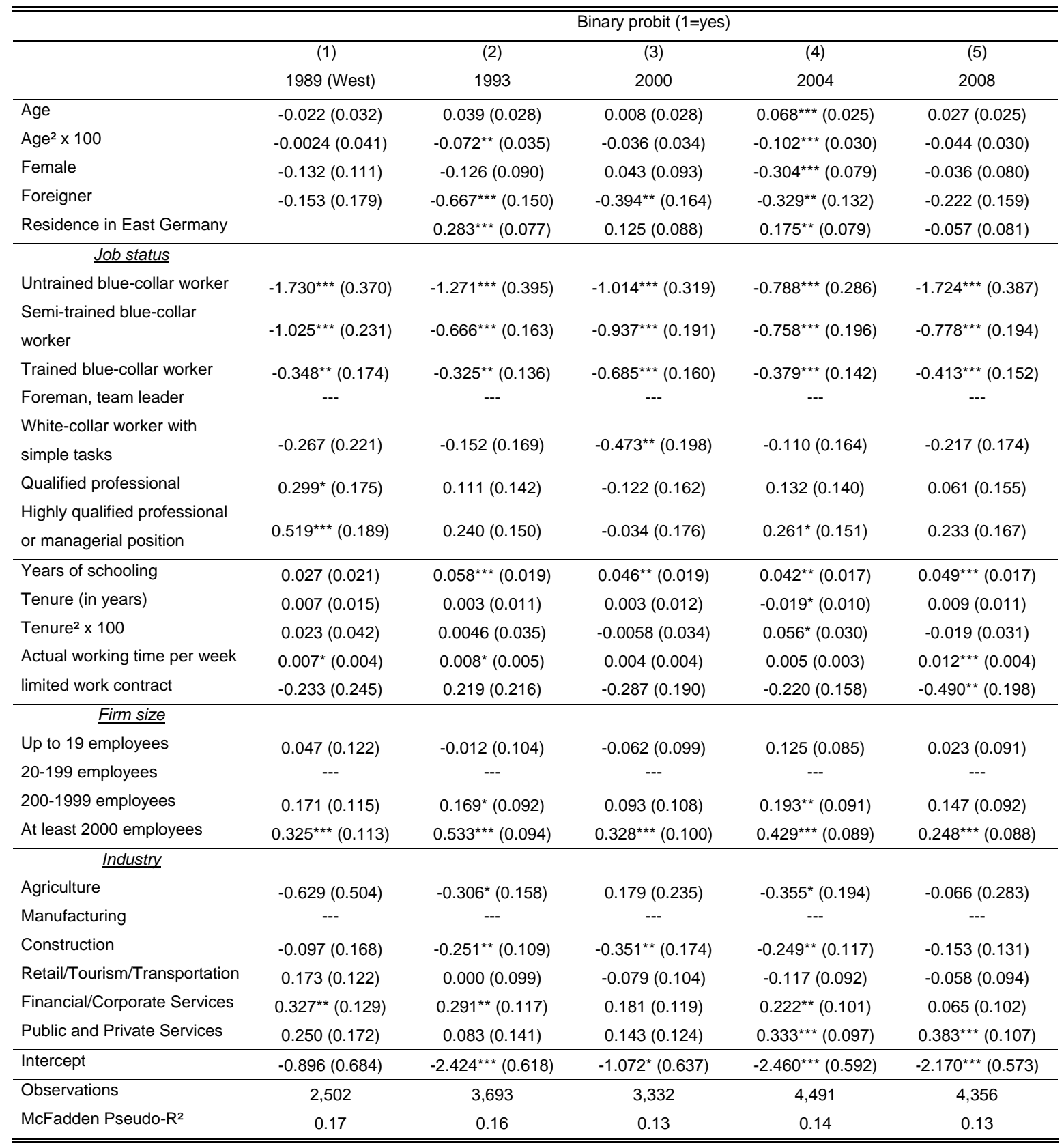

Notes: Robust standard errors in parentheses. The results are calculated with cross-sectional weights. 
Challenging our results, one may argue that we concentrate on training participation and abstain from analyzing any kind of training quality or intensity. For this purpose, possible indicators could be the length of the course or the productivity gain due to further training. Some studies like Pischke (2001) or Georgellis and Lange (2007) try to estimate some kind of training intensity by regressing the overall individual duration of training courses on possible determinants (measured in days respectively weeks). However, the explanatory power of these estimations is very low. This could arise from data restrictions as the GSOEP does not provide detailed information if the course was full-time or only some hours per day or week. Furthermore, information about the duration is only available for the last three courses. Nevertheless, we also estimated ordered probit models with a comparable specification using the number of courses within the one year period as the dependent variable. The qualitative results are similar to our binary probit estimates.

An important strand of literature focuses on the distinction between general and firmspecific human capital (see already Becker 1962). According to human capital theory, firms should not invest in general skills of employees as they are completely transferable to other firms and, hence, the training firm has little possibilities to save the earnings of the investment. However, Acemoglu and Pischke (1998) argue that the training firm has superior information with respect to the impact of the training course and the abilities of the employee. Hence, the firm has some kind of monopsony power against the worker. In consequence, the employer can amortize the costs of further training, even if it provides general knowledge and abilities. Indeed, there is some evidence by Acemoglu and Pischke (1998) or Büchel and Pannenberg (2004) that German firms companies bear at least part of the costs in most cases. Lazear (2009) argues that all skills are general, but a vector of certain general skills is used in different 
combinations and with different weights across companies. Therefore, most human capital investments within firms do have a specific character and, hence, also employers have incentives to invest in some mix if general human capital components of their employees.

As the GSOEP provides us with some information about the specificity of the training course (at least for one course in the years 1993 until 2008), we are able to estimate a multinomial probit model with a three-digit dependent variable with the categories "no training” (base), “rather firm specific training” and “rather general training”. Results are shown in Appendix 1 and reveal similar relations for both kinds of training. Since the characteristics hardly differ, we are convinced that a further distinction between general and firm specific human capital investments is not beneficial for this contribution.

\section{Conclusion}

Based on theoretical considerations, we investigate possible characteristics of participation in further training. We observe a period of twenty years from 1989 to 2008, using representative employee data from Germany. Our longitudinal analysis of the whole observation period provided support for most of our hypotheses. Looking on economic relevance, we find that being a foreigner, the job status and the firm size affects the training decisions most. The analyses of five single years' cross-sectional data from within the 20 year period reveal that these results are rather stable over time. Furthermore, we detect a general trend of an increasing training participation.

To check for the robustness of our results, we also differentiate between investments in general and specific human capital. It reveals that the determinants of those two kinds of investments are rather similar. Thus, the distinction between these two kinds of human 
capital seems to be of minor importance for the decision on further training participation.

We find a shrinking goodness of fit of our model with respect to the determinants of training over time, which seems to indicate that other factors become more important. Further research should investigate which other determinants (that are not included in our analysis) has become more relevant in the context of further training.

\section{References}

Acemoglu, D. and Pischke, J.-S. (1998) 'Why Do Firms Train? Theory And Evidence', The Quarterly Journal of Economics, February 1998: 79-119.

Akerlof, G.A. (1970) 'The Market for “Lemons”: Quality Uncertainty and the Market Mechanism’, Quarterly Journal of Economics, Vol. 84, Issue 3: 488-500.

Becker, G.S. (1962) 'Investment in Human Capital: A Theoretical Analysis', Journal of Political Economy, Vol. 70, Number S5: 9-49.

Behringer, F. (1999) Beteiligung an beruflicher Weiterbildung:

Humankapitaltheoretische und handlungstheoretische Erklärung und empirische Evidenz, Opladen.

Bellmann, L. (2003) Datenlage und Interpretation der Weiterbildung in Deutschland, Schriftenreihe der Expertenkommission Finanzierung Lebenslangen Lernens, Band 2.

Büchel, F. and Pannenberg, M. (2004) 'Berufliche Weiterbildung in West- und Ostdeutschland: Teilnehmer, Struktur und individueller Ertrag', Journal for Labour Market Research, Volume 31, Issue 2: 73-126.

Confederation of German Employers (2007) Berufliche Weiterbildung: Schlüssel zu Wettbewerbsfähigkeit und Beschäftigungsfähigkeit, Berlin.

Confederation of German Trade Unions (2009) Today for Tomorrow: Train qualified employees, press release from 30 March 2009. Online available under http://www.dgb.de/-/aXF 
Constant, A. and Massey, D.S. (2005) 'Labor market segmentation and the earnings of German guestworkers’, Population Research and Policy Review, 24: 489-512.

Doeringer, P. and Piore, M. (1971) Internal Labor Markets and Manpower Analysis, Lanham.

Erlinghagen, M. (2005) 'Wie lange dauert es, bis Beschäftigte ihren Betrieb verlassen? Neue Ergebnisse zur Beschäftigungsstabilität in West- und Ostdeutschland', IATReport 2005-9, Institut Arbeit und Technik Gelsenkirchen.

European Communities (2009) New Skills for New Jobs: Anticipating and matching labour market and skills needs, Luxembourg.

Frick, J.R., Haisken-DeNew, J.P., Spiess, M. and Wagner, G.G. (2005) 'Overview of the SOEP', in Haisken-DeNew, J. P. and Frick, J. R. (eds.) Desktop Companion to the German Socio-Economic Panel: chapter 1.

German Federal Ministry of Labour and Social Affairs (2009) Statistisches Taschenbuch 2009. Online available under http://www.bmas.de/portal/38586/statistisches_taschenbuch_2009.html.

Georgellis, Y. and Lange, T. (2007) 'Participation in continuous, on-the-job training and the impact on job satisfaction: longitudinal evidence from the German labour market', The International Journal of Human Resource Management, 18:6: 969985.

Haber, S.E. (1991) 'Participation in Industrial Training Programs', Small Business Economics, Volume 3, Number 1: 38-48.

Holtmann, A.G. and Idson, T.L. (1991) 'Employer Size and On-The-Job Training Decisions’, Southern Economic Journal, Vol. 58: 339-354.

Hubert, T. and Wolf. C. (2007) 'Determinanten der beruflichen Weiterbildung Erwerbstätiger. Empirische Analysen auf der Basis des Mikrozensus 2003’, Zeitschrift für Soziologie, Jg. 36, Heft 6: 473-493.

Lazear, E. (2009) 'Firm-Specific Human Capital: A Skill-Weights Approach’, Journal of Political Economy, Vol. 117, Issue 5: 914-940.

Leber, U. and Möller, I. (2008) 'Weiterbildungsbeteiligung ausgewählter Personengruppen’, Schmollers Jahrbuch, Issue 128: 405-429.

Mincer, J. (1992) Human Capital. A Review, Columbia University New York, Discussion Paper Series No. 591.

Pannenberg, M. (1995) Weiterbildungsaktivitäten und Erwerbsbiographie: eine empirische Analyse für Deutschland, Frankfurt am Main and New York. 
Pannenberg, M. (1998) 'Weiterbildung, Betriebszugehörigkeit und Löhne:

Ökonomische Effekte des „timings“ von Investitionen in die berufliche Weiterbildung'. In Pfeifer, F. and Pohlmeier, W. (eds.) Qualifikation, Weiterbildung und Arbeitsmarkterfolg, Baden-Baden, pp. 257-278.

Pischke, J.-S. (2001) 'Continuous Training in Germany’, Journal of Population Economics, 14: 523-548.

Spence, M. (1973) 'Job Market Signaling', Quarterly Journal of Economics, Vol. 87 Issue 3: 355-374.

Wolter, F. and Schiener, J. (2009) 'Einkommenseffekte beruflicher Weiterbildung. Empirische Analysen auf Basis des Mikrozensus-Panels’, Kölner Zeitschrift für Soziologie und Sozialpsychologie, 61 (1): 90-117.

Wooldridge, J. (2002) Econometric analysis of cross section and panel data, Cambridge.

Zwick, T. (2005) 'Continuing Vocational Training Forms and Establishment Productivity in Germany’, German Economic Review, Volume 6, Issue 2: 155184. 


\section{Appendix 1: Determinants of firm-specific and general further training (multinomial probit estimate, pooled)}

\begin{tabular}{|c|c|c|}
\hline & \multicolumn{2}{|c|}{ Multinomial probit (base $=$ no training) } \\
\hline & firm-specific & general \\
\hline Age & $0.038^{* *}(0.019)$ & $0.053^{* * \star}(0.015)$ \\
\hline $\mathrm{Age}^{2} \times 100$ & $-0.065^{\star * \star}(0.023)$ & $-0.091^{\star \star \star}(0.019)$ \\
\hline Female & $-0.314^{\star \star \star}(0.058)$ & $-0.068(0.049)$ \\
\hline Foreigner & $-0.469^{\star \star \star}(0.100)$ & $-0.525^{\star \star \star}(0.086)$ \\
\hline Residence in East Germany & $0.184^{\star \star \star}(0.054)$ & $0.092^{* *}(0.046)$ \\
\hline \multicolumn{3}{|l|}{ Job status } \\
\hline Untrained blue-collar worker & $-1.049^{\star * \star}(0.257)$ & $-1.645^{\star \star *}(0.243)$ \\
\hline Semi-trained blue-collar worker & $-0.716^{\star * \star}(0.125)$ & $-1.257^{\star * \star}(0.110)$ \\
\hline Trained blue-collar worker & $-0.306^{\star \star \star}(0.104)$ & $-0.597^{\star \star \star}(0.085)$ \\
\hline Foreman, team leader & --- & --- \\
\hline White-collar worker with simple tasks & $-0.066(0.121)$ & $-0.394^{\star \star \star}(0.100)$ \\
\hline Qualified professional & $0.218^{\star *}(0.105)$ & $0.105(0.086)$ \\
\hline Highly qualified professional or managerial position & $0.235^{\star \star}(0.111)$ & $0.353^{\star \star \star}(0.090)$ \\
\hline Years of schooling & $0.037^{\star \star \star}(0.012)$ & $0.042^{\star \star \star}(0.010)$ \\
\hline Tenure (in years) & $-0.008(0.008)$ & $-0.055^{\star \star \star}(0.020)$ \\
\hline Tenure $^{2}$ x 100 & $0.037(0.023)$ & $0.001^{\star * \star}(0.000)$ \\
\hline Actual work time per week & $0.003(0.003)$ & $0.011^{\star \star \star}(0.002)$ \\
\hline limited work contract & $-0.274^{\star *}(0.136)$ & $-0.134(0.107)$ \\
\hline \multicolumn{3}{|l|}{ Firm size } \\
\hline Up to 19 employees & $-0.024(0.067)$ & $0.025(0.053)$ \\
\hline 20-199 employees & --- & --- \\
\hline 200-1999 employees & $0.352^{\star \star \star}(0.065)$ & $0.189^{\star \star \star}(0.054)$ \\
\hline At least 2000 employees & $0.693^{\star \star \star}(0.063)$ & $0.413^{\star \star \star}(0.053)$ \\
\hline \multicolumn{3}{|l|}{ Industry } \\
\hline Agriculture & $0.330 * \star(0.134)$ & $-0.187(0.137)$ \\
\hline Manufacturing & --- & --- \\
\hline Construction & $-0.228^{\star \star}(0.100)$ & $-0.191^{\star \star}(0.078)$ \\
\hline Retail/Tourism/Transportation & $-0.020(0.064)$ & $-0.130^{\star *}(0.054)$ \\
\hline Financial/Corporate Services & $0.138^{\star}(0.073)$ & $0.181^{\star \star \star}(0.060)$ \\
\hline Public and Private Services & $0.419^{\star \star \star}(0.077)$ & $0.413^{\star \star \star}(0.064)$ \\
\hline \multicolumn{3}{|l|}{$\underline{\text { Year }}$} \\
\hline 1993 & $-0.157^{\star \star}(0.073)$ & $-0.028(0.059)$ \\
\hline 2000 & --- & --- \\
\hline 2004 & $0.054(0.064)$ & $-0.024(0.054)$ \\
\hline 2008 & $0.182^{\star \star \star}(0.064)$ & $0.144^{\star \star \star}(0.054)$ \\
\hline Intercept & $-3.105^{\star \star \star}(0.420)$ & $-2.867^{\star * \star}(0.349)$ \\
\hline Observations & \multicolumn{2}{|c|}{15,777} \\
\hline
\end{tabular}

Note: Standard errors in parentheses. 